\title{
Political Dynamics of Candidate Recruitment: A Case Study of Nasdem Party in Pilkada of North Sumatera in 2018
}

\author{
Fifi Silfita; Humaizi; Abdul Kadir \\ Faculty of Social and Political Sciences, Universitas Sumatera Utara, Medan, Indonesia
}

http://dx.doi.org/10.18415/ijmmu.v6i3.924

\begin{abstract}
This study aims to explain how the political dynamics in National Democratic party or Partai Nasional Demokrat (Nasdem) in the selection process of the candidates for the governor-deputy governor in pilkada of North Sumatera in 2018, and to explain what factors that affect the decision in that process. This study employed qualitative method. The location of this research was at the office of the regional representative council (RRC) of Nasdem party of North Sumatera. The technique of data collection was by using the interview method. The informants were the chairperson of the regional representative council and the chair of the winning team for the general election of the Nasdem party. The results of this study indicate that the candidcay in political recruitment or selection conducted by the RRC of Nasdem party of North Sumatera province uses an inclusive model. The determination of selectorate utilized exclusive model. The determination of where the candidate selection used centralistic pattern or model. The decision making procedure for determining the candidates was by using candidate pattern with more democratic selection principles. The factors behind the RRC of Nasdem party of North Sumatera province in supporting Eramas as the candidates of the governor-deputy governor of North Sumatera for 20182023 period are influenced by the strength of the large party and also the choice of the profit and loss vote in 2019 even though they had a process or mechanism in the party internal system.
\end{abstract}

Keywords: Political Dynamics; Nasdem Party; Political Recruitment; Pilkada of North Sumatera

\section{Introduction}

Political parties are one of the democracy elements. Budiardjo (2008) said that political parties are a group of people who are organized to seize or maintain power, with the intention of welfare of its members, both for fairness policies and for material matters. According to Russell J.Dalton and Martin P. Wattenberg in Pamungkas (2011), party functions are divided into three namely parties in the electorate, parties in the organization, and parties in the government. Political parties should be seen as a momentum for the birth of new freedoms and a reflection of high political participation from the community, but in reality, the multi-party system backfires democracy. They become "mouthpieces" for a group of people who try to complain of luck in the party through elections, without being accompanied by truly screening process. 
In a democratic political system, it is agreed on how to fill political positions through a periodic, open, free and fair election (Fitriyah, 2018). One of the various implementations of the democratic system in Indonesia is through regional head election of pemilihan kepala daerah (henceforth: Pilkada). This activity is a procedure with a mechanism that provides freedom for the people to choose leaders in their area (Pratikno, 2007). On the other hand, it is also a process of strengthening and deepening democracy and efforts to realize good and effective governance Hanafi (2014). Pilkada in 2018 were held in 17 provinces, 115 districts and 39 cities with direct election systems, namely one man, one vote. It also includes North Sumatera province which took part in the election of the governor-deputy governor for 2018-2023 period. The year of 2018 is regarded as the political year or electoral year. It becomes the starting point for political contestation which is full of calculations of electability figures (Tedjo, 2018). If there is wrong calculation or prediction, it will certainly have a huge impact.

There are two official pair candidates for pilkada of governor-deputy governor of North Sumatera province for 2018-2023 period. The election day of pilkada was held on $27^{\text {th }}$ June, 2018. The first pair is Lieutenant General (Retired) Edy Rahmayadi and Musa Rajeckshah (they have jargon as ERAMAS). The second one is Djarot Saiful Hidayat and Sihar Sitorus (their jargon is JOSS). Eramas candidate, firstly, registered to Hati Nurani Rakyat (Hanura) party in August 2017. Gerindra, PKS and PAN parties then gave their support to this pair at the end of December 2017. There is one phenomenon, although Golongan Karya (Golkar) party and Nasional Demokrat (Nasdem) had expressed their support for Tengku Erry Nuradi (TEN) which also the incumbent, eventually, they transferred their support and recommendation to Eramas. Actually, in this Pilkada, golkar party at first attempted to join Tengku Erry Nuradi, the chairman of RRC of Nasdem Party, with Ngongesa Sitepu, as the chairman of Golkar party in North Sumatera. Then, in its process, Ngongesa Sitepu resigned as North Sumatera deputy governor candidate because of heart disease. (https:// regional.kompas.com / read / 2017 /11 / 16 / 06520091 / nasdem - kami-kehilangan-sosok-yang-layak-mendampingi-tengku-erry diakses 12 April 2018).

On Sunday, $12^{\text {th }}$ November 2017, at Lapangan Merdeka on Pulau Pinang Street, Medan, Nasdem declared Tengku Erry Nuradi as governor candidate for pilkada in the 2018. But unluckily, Nasdem only had five regional representative members or it needs 15 seats to follow the minimum requirement to propose the candidate of the governor. Like or not, Tengku Erry Nuradi should be sincere not to take part in the election. Tragically, he had to hand over the recommendation of Nasdem to his rival even though he is the head of RRC of Nasdem party of North Sumatera. He, at first, was supported by Golkar (17 seats), Nasdem (5 seats), Partai Kebangkitan Bangsa (PKB) (3 seats), and Partai Keadilan dan Persatuan Indonesia (PKPI) (3 seats). But, one by one, he was abandoned by his supporters. They choose to recommend and support other candidates.

What has been done by Nasdem party, which ultimately voted for Eramas, was part of political dynamics and political recruitment. Agustino (2009) revealed that political dynamics is very much related to the issue of participation and democracy. The issue of participation has long been discussed, but it is still problematic. One of the reasons is the bias of the authorities. When participation is interpreted as participation in fulfilling government agendas, the medium provided is only bureaucratic-technocratic: the mechanism of planning from below, the selection of aspirations and the like. Dwiyanto et al. (2002) views that political dynamic is a description of how far the political process takes place that can reflect democratic values and accountability.

The treatment of political parties in the whole stages of political recruitment is closely related to how political parties organize themselves. Haryanto (1982) defines recruitment as a solution for talented individuals to be able to occupy political positions and government positions. Cholisin et al. (2007) add that political recruitment is the selection and appointment of a person or group to carry out a number of roles in the political system in general and government in particular. Recruitment can also be in the form of open or closed recruitment (Tangkilisin, 2003). In determining its choices, political parties in the 
political recruitment process consider several matters which include partisan, compartmentalization, and immediate survival.

Rahat and Hazan in Pamungkas (2012) assert that there are 4 (four) important things that can show how organizing political parties in political recruitment, namely candidacy, selectorate, where candidates are selected, and how candidates are decided. The treatment of these four issues gave birth to a party management model between inclusive vs. exclusive, centralistic vs. decentralized, democratic vs. authoritarian models, and the midpoint between these extremes. Regarding who can be nominated in political recruitment, it can be classified based on the level of inclusive or exclusive. In an inclusive model, each voter can be a party candidate. The restrictions are only regulations that are set by the state. Meanwhile in the model, there are exclusive conditions that limit the right of voters to be able to participate in candidate selection. Political parties provide a number of additional requirements beyond those specified by the state. State regulations usually lay down the basic requirements for individuals who may nominate themselves, including the requirements for age, citizenship, residence, literacy qualifications, deposit limits, amount of support, etc. Therefore, the process of political recruitment is a long process and full of consideration.

Nasdem party is the members of the ruling party coalition. But, their decision for pilkadai of North Sumatera for choosing governor, they joined the coalition with opposition parties such as Gerindra or PKS. Although the party coalition was presented with positive-purpose packaging in the region, it was allegedly caused a big question whether there were personal or group interests that it could always lead to political instability. When people ask about coalition changes, they answer, "it is political dynamic". Pilkada was designed as a democratic process in choosing leaders in the regions, but it has turned out to be directed as a medium for local elites and political parties to make political dramas as if they were competitive and democratic (Nurprojo, 2016).

The political phenomenon of the shift of Nasdem's support and recommendation to Eramas candidate is an interesting phenomenon. Rani (2018) said that political parties in determining candidate pairs in the 2018 regional election turned out to pay more attention to the electoral dimension, electability, and contributions of candidate pairs in the local political space. This is what causes a very significant difference in the number of party coalitions and ideologies in one candidate pair, both at the provincial, district and city levels. The phenomenon happened in pilkada of North Sumatera in 2018 is an interesting thing to be explored, especially regarding to the dynamics of the recruitment process done by Nasdem party.

There are some related researches dealing with political dynamics in pilkada. Wijayanto (2016) attempted to see the process of political dynamic of the recruitment process by Partai Demokrasi Indonesia Perjuangan (PDIP) in Pilkada of Wonogiri regency. He concluded that the process done by the regional representatives followed the mechanism determined by the centre of PDIP. They do not have any authority to give direct recommendation. Another research, Situmorang (2016) deals with exploring how Partai Kebangkitan Bangsa (PKB) recruits the candidates to participate in pilkada. They open the selection process, but the selectorate is exclusive. There is also desk team from the branch but the recommendation is from the centre of PKB. The previous researches are clearly different from this study in terms of the object and the location of the research. In accordance with the problems in advance, the purpose of this study is to explain how the political dynamics in Nasdem party in the process of selection of candidates for the governor of North Sumatera in 2018 and explain what factors determine the decision of this party in the process of selection. 


\section{Method}

This study employed the qualitative design. The location of this research was at the office of the regional representative council of Nasdem party of North Sumatera located on at Jalan. Mongonsidi No.30 Medan. The data collection technique was by using the interview method. The informants in this study were the chairperson of the regional representative council and chair of the winning team for the general election of the Nasdem party in North Sumatera.

\section{Results}

The Profile of the Regional Representative Council of Nasdem Party of North Sumatera

Nasdem party is one of political parties in Indonesia. It was inaugurated at Mercure Ancol Hotel, North Jakarta on July 26, 2011. The party is founded by Surya Paloh who is the founder of the same organization namely the Nasional Demokrat (https://www.partainasdem.id/pages/sejarah-partai-nasdem). In January 2013, the general election commission or Komisi Pemilihan Umum (KPU) determined 10 political parties that had passed the administrative and factual verification stages, and made the Nasdem the only new party to qualify as a participant in 2014 election. This party has a concrete vision and mission (Indonesian Restoration). This party has a vision namely an independent Indonesia as a nation state, economically sovereign, and dignified in culture. In each province, there is an office of the regional leadership council. The representative of Nasdem party of North Sumatera is led by Iskandar, S.T. as the chairperson, and H. Syarwani, SH as the secretary.

\section{The Internal Political Dynamics of Nasdem Party in Pilkada of North Sumatera in 2018}

There are frequent discussions in the regional members of Nasdem party in North Sumatera which also involved the incumbent led by Tengku Erry Nuradi before his resignation at that time as the chairman. Starting from there, the agreement and negotiation began, with initial communication which initially discussed who would be supported in the race of North Sumatera Pilkada to choose the governordeputy governor for the $2018-2023$ period. The offer was first given to Tengku Erry Nuradi because he was ready as the incumbent to participate in. But, at the end, after considering the aspirations of the community and the most votes in North Sumatera province, they continued to change the choice of support to Eramas candidate.

The results of the offer and consideration leading to the replacement of the candidates were based on the regulation of Nasdem party. It is stated by the informant, Mr. Salman Ginting as Chairman of Badan Pemenangan Pemilu of RRC of Nasdem party.

"The RRC asked for input from the grassroot and then analyzed with various considerations of accessibility, capability and popularity which then considered other aspects that could decide that Mr. Edy Rahmayadi and his partner Ijeck (Musa Rajeckshah) to replace Mr. Tengku Erry Nurady as the candidate for the Governor of North Sumatera at the time" (Ginting, 2019)

It means that the RRC of Nasdem party of North Sumatera is sure about the ability of Eramas candidate to fight in the North Sumatera pilkada as a candidate for the governor-deputy governor for 2018-2023 period. There are several formal and informal factors that make them more realistic especially in a party organization. Furthermore, talking about the reality of political interests, it has been explained 
that from the point of view of reality, even though they have proposed selection candidates such as Tengku Erry Nuradi, it does not mean they have the right to occupy positions offered or supported by the Nasdem Party structurally. Instead, they place themselves as a part of a process prepared to obtain someone who fits the criteria set and benefits the party going forward. Some considerations that reinforce the political dynamics in the internal of North Sumatera Nasdem party merely to win the votes of the people of North Sumatera in the interests of the victory of the Nasdem party cadres themselves for the next general election. This was confirmed by Mr. Salman Ginting as the following:

"All must be started from the beginning, each party wants its cadres to become leaders starting from the lowest party machine from the level of regional branch leadership boards, branches, regional, and center. Therefore all machines in all levels want the victory of their cadres." (Ginting, 2019)

There is a fear that the tendency of political parties like this also reflects what has happened lately in Indonesia. to set candidates for regional heads to compete in elections is more based on aspects of popularity and stability, not on aspects of accessibility and the ability of candidate in which electability and acceptability can be engineered.

\section{The Candidacy \& Candidate Selection}

In Nasdem party, the institution that selects candidates for regional head is called the selection team or committee of selection at the central level or Dewan Pimpinan Pusat (DPP). The committee has cumplosory to select and screen the governor candidates who have registered through Nasdem party of North Sumatera. In the level of region, the process was only based on administrative selections. This means that the committee only verified incoming data from prospective candidates who had registered. But their authority was limited such as to conduct socialization related to the opening of the registration, to screening, and to conduct administrative selection. In the recruitment process in Nasdem party of of North Sumatera, the full authority is in DPP. Furthermore, the candidate selectors are appointed by DPP of Nasdem party. So, in the selection process, the neutrality of the assessor cannot be determined. Then, the selection of candidates in this party cannot be said to be ideal because the selection of candidates for regional head candidates is only focused on DPP and does not involve people outside the party. It shows the method used in this process called the centralistic method (Rahat and Hazan in Pamungkas, 2011). This is also reinforced by the statement below:

"We always coordinate with the DPP because whatever it is, the DPP has the authority to decide especially this is the matter of determining the Governor.It is their territory and authority. They also consider suggestion from regional members. But, we, as the managers in region, we must obey the rules of the party." (Ginting, 2019)

\section{Nominating the Candidate}

According to Rahat and Hazan in Pamungkas (2012), in deciding the regional head candidates, there are two models namely the candidate selection model (Democratic) and the designation model (Authoritarian). The selection model is a model where all regional head candidates are selected through existing selection procedures, without a selector can change the composition list. Whereas, the second model use a pure designation model where candidates will only be appointed by party leaders without going through the selection process that follows. The candidates are appointed without the need for approval by other party agencies except nominations by party or party leaders. 
Regarding the decision making process towards candidates, what happens in the Nasdem party is that every candidate who will take part in the nomination market still has to follow the selection stage or process in accordance with the procedures stipulated by DPP through the selection committee at the central level to the regions. In the selection of candidates, for North Sumatera Governor, it is through a coalition mechanism. This became the basis / reference for the regional leadership council to provide support to Eramas. In determining who gets the party recommendations, it is collegial collective. It means that to decide who will get recommendations from the regional representative of Nasdem party will be conducted through the internal meeting of DPP Nasdem party and not unilaterally decided.

In the nomination of Edy Rahmayadi, it is undeniable that the shift of support caused by the political situation in the region was mainly influenced by large parties. The advantages of Edy Rahmayadi himself are, among others, seen as a key figure for the vote to the legislature. So, even though Edy Rahmayadi is not a party cadre but he is seen as having commitment, consequences, and loyalty, it will certainly be higher than the party cadres themselves. Moreover, he is considered to have a link / communication to the investors for political lobbies related to the policies that will be made. The above is one of the factors of his excellence.

From the description above, it can be seen the background of the Nasdem Party in choosing EdyIjeck (Eramas) as a candidate for governor-deputy governor in 2018. In terms of mechanisms and selection of candidates applied by the Nasdem Party, its DPP had set the regional representative level to follow the prepared mechanism. In terms of assessment and place of selection, it is obviously the authority of DPP Nasdem party. Then in decision making, it is the result of the assessment of the selection process followed by each candidate. The party conducting the assessment is from the assessment team assigned from the DPP Nasdem party. But what happened to the Nasdem party in this pilkada shows that this party is still weak because it depends on the party that has the largest vote. Then, Nasdem party in the area is allegedly controlled more by the political party elite itself. The authority of over the process of recruiting regional head candidates is in DPP. The regional representative only has little authority, namely to conduct screening and administrative selection only.

\section{Conclusion}

The mechanism of candidacy in political recruitment or selection conducted regional representative of Nasdem party of North Sumatera Province uses an inclusive model because all can be candidates for the governor and deputy governor of North Sumatera. This is conducted in an open and transparent manner. The determination of selectorate is done by using an exclusive model. Selection is carried out exclusively where candidation is determined by the DPP. More detail is called the informallong distance pattern system, because starting from the procedure or mechanism until recruitment is determined by DPP. The determination of the selection used a centralized pattern or model. This means that the selection of candidates for regional heads is focused / centered on the DPP. Finally, the procedure for finalizing the candidates is by using candidate patterns with more democratic selection principles. In determining who gets recommendations, it is also based on the results of the selection process starting from the registration stage to the final stage. To determine who gets the recommendations, it is also through internal meetings of DPP Nasdem party because the party considers other factors that can influence the party's future votes. The factors behind the RRC of Nasdem party of North Sumatera province in supporting Eramas as the candidates of the governor-deputy governor of North Sumatera for 2018-2023 period are influenced by the strength of the large party and also the choice of the profit and loss vote in 2019 even though they had a process or mechanism in the party internal system. 


\section{References}

Books

Agustino, L. (2008). Dasar-Dasar Kebijakan Publik. Bandung: Alfabeta.

Dwiyanto, A. et al. (2002). Reformasi Birokrasi Publik Di Indonesia. Yogyakarta : Galang Printika.

Budiardjo, M. (2008). Dasar-dasar Ilmu Politik. Jakarta. PT. Gramedia Pustaka Utama.

Cholisin, et al. (2007). Dasar-Dasar Ilmu Politik. Yogyakarta: UNY Press.

Haryanto. (1982). Sistem Politik: Suatu pengantar. Yogyakarta: Liberty.

Pamungkas, S. (2011). Partai Politik dan Praktek di Indonesia. Yogjakarta: Institute For Democracy and Welfarism Syafiie.

Pamungkas, S. (2012). Partai Politik. Yogyakarta.PT. Perum Griya Saka Permai.

Tangkilisan, H. N. (2003). Kebijakan Publik yang Membumi. Yogyakarta: Yayasan Pembaruan Administrasi Publik Indonesia.

Wijayanto, I. (2016). Dinamika Rekrutmen Politik Calon Kepala Daerah dalam Pemilukada Serentak Tahun 2015 (Studi Kasus Dewan Pimpinan Cabang Partai Demokrasi Indonesia Perjuangan Kabupaten Wonogiri). [student paper]. Yogyakarta: Universitas Muhammadiyah Yogyakarta.

\section{Journal}

Fitriyah. (2018). Politik Dinasti pada Kandidasi Perempuan dalam Pilkada Serentak 2015 di Jawa Tengah Jurnal Ilmu Sosial, 17(1), 39-52.

Hanafi, R. I. (2014). Pemilihan Langsung Kepala Daerah di Indonesia: Beberapa Catatan Kritis untuk Partai Politik. Jurnal Penelitian Politik, 11(2), 1-6.

Nurprojo, I. S. (2016). Bagongan, Pilkada Serentak dan Demokrasi yang Cedera: Belajar dari Purbalingga. Politik Indonesia: Indonesian Political Science Review, 1(2), 120-135.

Pratikno. (2007). Calon Independen, Kualitas Pilkada dan Pelembagaan Parpol. Jurnal Ilmu Sosial dan Ilmu Politik, 10(3), 415-438.

Rani, S. (2018). Dinamika Komunikasi Politik dalam Pilkada di Indonesia. Jurnal Alhadharah, 17(33), 112-128.

Situmorang, T. (2016). Dinamika Politik Internal Partai Kebangkitan Bangsa dalam Proses Penentuan Kandidat Calon Wakil Bupati Sidoarjo 2015. Jurnal Politik Muda, 5(3), 342 - 352.

Tedjo, P. (2018). Peran Demokrasi, Pilkada Serentak tahun 2018 Tantangan dan Harapan. Mimbar Administrasi, 2(1), 21-29. 


\section{Web Publication}

Admin. (2019). Sejarah Partai Nasdem. Retrieved from https://www.partainasdem.id/pages/sejarah-partaiNasdem

Leandha, M. (2017). Nasdem: Kami Kehilangan Sosok yang Layak Mendampingi Tengku Erry Retrieved from https://regional.kompas.com/read/2017/11/16/06520091/nasdem-kami-kehilangan-sosokyang-layak-mendampingi-tengku-erry.

\section{Copyrights}

Copyright for this article is retained by the author(s), with first publication rights granted to the journal. This is an open-access article distributed under the terms and conditions of the Creative Commons Attribution license (http://creativecommons.org/licenses/by/4.0/). 